\title{
HIV-1 infection and circulating peripheral blood $B$ cell subpopulations
}

\author{
Ravinder Singh ${ }^{1 *}$, Neema Negi ${ }^{2}$, Bimal Kumar Das ${ }^{2}$, Rakesh Lodha' ${ }^{1}$, SK Kabra ${ }^{1}$, Madhu Vajpayee ${ }^{2}$ \\ From 2nd International Science Symposium on HIV and Infectious Diseases (HIV SCIENCE 2014) \\ Chennai, India. 30 January - 1 February 2014
}

\section{Background}

Progression of HIV-1 infection can be monitored by studying the frequency of B cell subpopulations which could serve as a better surrogate marker. The study evaluated the distribution as well as the frequency of B cell subsets in peripheral blood of HIV-1 infected Indian individuals.

\section{Methods}

In HIV infected, ART naïve adults and healthy controls, frequency of B cell subpopulations were measured by flow cytometry. Difference between groups was compared using Student $\mathrm{t}$ test and $p$ value of $<0.05$ was considered significant.

\section{Results}

In HIV infected adults, a significant reduction in nonswitched memory B cells $(\mathrm{CD} 19+\operatorname{IgD}+\mathrm{CD} 27+)$ was observed, compared to healthy controls $(p=0.046)$. With ongoing viral replication and reduced CD4 count, an expansion in $\mathrm{CD} 21^{\mathrm{lo}} \mathrm{CD} 27^{-}$(tissue like memory) population was observed and the correlation was statistically significant $(p=0.0004)$. The mean frequency of CD21 ${ }^{\text {hi }} \mathrm{CD} 27^{\mathrm{hi}}$ (resting memory) was significantly higher in controls $(p=0.0002)$ compared to HIV-1 infected adults, while tissue like memory were highly expanded in HIV infected adults compared to controls $(p=0.0001)$. B cells in HIV-1 infected adults expressed higher frequency of CD95 compared to healthy controls $(p=0.0004)$.

\section{Conclusions}

HIV mediated alteration in B cell development and differentiation may result in loss of switched and non-switched

\footnotetext{
* Correspondence: ravinder.rathore.singh@gmail.com

'Department of Pediatrics, All India Institute of Medical Sciences, New Delhi, India

Full list of author information is available at the end of the article
}

memory B cells. Moreover, association of persistent viremia with expansion of $C D 21^{\text {lo }}$ tissue like memory cells suggests loss of CD21 expression as a marker of ongoing HIV replication. B cells in HIV-1 infected adults are more prone to Fas mediated apoptosis compared to healthy controls.

\section{Authors' details}

${ }^{1}$ Department of Pediatrics, All India Institute of Medical Sciences, New Delhi, India. ${ }^{2}$ Department of Microbiology, All India Institute of Medical Sciences, New Delhi, India.

Published: 27 May 2014

\section{doi:10.1186/1471-2334-14-S3-O6}

Cite this article as: Singh et al:: HIV-1 infection and circulating peripheral blood B cell subpopulations. BMC Infectious Diseases 201414 (Suppl 3):06.
Submit your next manuscript to BioMed Central and take full advantage of:

- Convenient online submission

- Thorough peer review

- No space constraints or color figure charges

- Immediate publication on acceptance

- Inclusion in PubMed, CAS, Scopus and Google Scholar

- Research which is freely available for redistribution

Submit your manuscript at www.biomedcentral.com/submit
() Biomed Central 